\title{
Detection and Estimation of Genetic and Environmental Parameters through Model Fitting of Ten Bulb Yield Contributing Traits in Onion
}

\author{
Anil Chandra DEB ${ }^{1}$ Rumman ARA ${ }^{2}$
}

${ }^{1}$ Department of Genetic Engineering and Biotechnology, University of Rajshahi, Rajshahi-6205, Bangladesh

2 Bangladesh Agricultural Research Institute (BARI), Joydebpur, Dhaka, Bangladesh

\section{Article History}

Received 21 March 2021

Accepted 29 May 2021

First Online 08 June 2021

\section{Corresponding Author}

E-mail: debac@ru.ac.bd

\section{Keywords}

Allium cepa L.

Bulb yield

$\mathrm{G} \times \mathrm{E}$ interaction

Genetic parameters

Onion

\begin{abstract}
Two onion varieties $P_{2}$ and $P_{3}$ and their products $F_{1}$ and $F_{2}$ were evaluated in summer and winter seasons for this investigation. Estimated mean values of different traits showed variations from generation to generation in each season. Values of six-parameters viz., $\widehat{m},[d],[h], e_{1}, g d_{1}, g h_{1}$ for all the characters were significant except $\mathrm{gd}_{1}$ for a number of leaves, leaf length and bulb volume and also [d] for leaf length and neck length. Overall means ' $\hat{m}$ ' had the highest magnitude than [d], [h], $e_{1}, g_{1}$ and $g h_{1}$ for all the characters. Environmental parameter ' $e_{1}$ ' also exhibited higher magnitude than [d], $g_{1}$ and $\mathrm{gh}_{1}$. As the values of [d] and $\mathrm{gd}_{1}$ were found to be non-significant, 4parameter model was considered for leaf length only. Five-parameter model was considered for neck length, number of leaves and bulb volume and for rest of the traits 6 -parameter model was considered. The goodness of fit test showed that 4, 5 and 6-parameter models were not adequate except bulb length and neck length. Therefore, for the development of these two traits in consideration of genotype $\times$ environment $(G \times E)$ interaction proper design and analysis needs to be done. Due to significant $\chi^{2}$ values for other characters the situations becoming more complex as $\mathrm{G} \times \mathrm{E}$ interaction model is inadequate, so for their exact genetic explanation $\mathrm{G} \times \mathrm{E}$ model needs to be extended to include linkage and non-allelic parameters.
\end{abstract}

\section{Introduction}

Onion (Allium cepa L.) a member of the family Alliaceae is one of the most important spice crops grown all over the world. The use of onion is not limited to any climate or associated with nationality. It is popularly used both at immature and mature bulb stages as a vegetable and as a spice. Onion compared with other fresh vegetables, are relatively higher in food energy, intermediate in protein content, and rich in calcium and riboflavin. Onion has diuretic properties, beneficial to the digestive tract, good for the eyes, to act as a heart stimulant and useful as an anti-rheumatic remedy. It is a slowgrowth, shallow-rooted crop with non-shading habitus and therefore its productivity is highly dependent on water availability in the soil, proper fertilization and weed control (Sekara et al., 2017).
As most commonly grown vegetable onion is on the list of 15 , with respect to its importance, it has been provided the second rank following tomato and with respect to production, it takes the fourth rank in the world (Jahromi and Amirizadeh, 2015). Among the spice grown in Bangladesh, onion is grown in 172460 ha and produced 1802868 metric tons (Mt) in terms of area and production during the year of 2018-2019 (BBS, 2019). Still, now Bangladesh is not sufficient in onion production though the per hectare yield and production increases but area decreases in the subsequent year (BBS, 2019). In this country, the average bulb yield of onion is $10447 \mathrm{~kg} \mathrm{ha}^{-1}$ (BBS, 2019). World dry bulb onion production increased 2.34 times between 1978 and 2002, whereas the population increased 1.45 times. The area under cultivation increased by a factor of 1.90 to 2.95 million ha in 
this interval, and the world average yields increased from 14.04 to $17.40 \mathrm{t} \mathrm{ha}^{-1}$ (Brewster, 2008). Due to lack of quality seeds and improved varieties as well as improper cultural practices the yield level of onion is quite low (approximately $370-500 \mathrm{~kg} \mathrm{ha}^{-1}$ ) as compared to the higher yield $\left(1000-1200 \mathrm{~kg} \mathrm{ha}^{-}\right.$ 1) produced in other countries (Mila and Parvin, 2019). World production of onions and shallots (as green produce) was 4.5 million tons, led by China with $22 \%$ of the world total, and Japan, Mali and South Korea as secondary producers (FAO, 2019). Looking to the importance and production of this crop greater attention is needed for its improvement. Therefore, efforts should be made to develop high yielding varieties through breeding research. But the success of the breeding plan depends on the knowledge of genetic variability of population, about the nature and different gene actions governing the various quantitative traits. The breeder should able to determine in predicting the magnitude and extent of the effects of genotype $\times$ environment $(G \times E)$ interaction as an expression of genes, which are mostly related to environmental features.

The study of quantitative traits becomes complicated when more than one environment is included because changes in gene expression may occur with changes in environments. These changes, observable as $G \times E$ interaction in biometrical analysis, has long been recognized as an important source of phenotypic variation (Immer et al., 1934; Yates and Cochran, 1938; Mather, 1949). For specifying, estimation and correcting the effects of $G \times E$ interaction two main approaches have been used under regression.

The first one purely statistical analysis originally proposed by Yates and Cochran (1938) which was later on modified by Finlay and Wilkinson (1963) and Eberhart and Russell (1966). The second approach is based on fitting of models which specifying the contribution of genetic and environmental effects and $\mathrm{G} \times \mathrm{E}$ interaction to generation mean and variance due to the contributions of additive, dominance and epistatic gene effects on the genetic and interaction components. This approach has been used by Mather (1949) and Jinks and Mather (1955), followed by Bucio Alanis (1966a), Bucio Alanis and Hill (1966b) and Perkins and Jinks (1968).

The study of $G \times E$ interaction in its biometrical aspects are important not only from genetic and an evolutionary point of view but also necessary to the agricultural production problem in general and particularly for plant breeding problems (Breese, 1969). Comstock and Moll (1963) reported that selection is impeded due to large effect of $G \times E$ interaction, knowledge about the description, prediction and inheritance of genotype interaction would provide more information and help the breeders to select better genotypes.

The breeding of adaptable onion varieties requires genotypes that have high stability for one or more quantitative traits. Information about adaptive potential and gene effects in onion are scanty for large scale exploitation inbreeding program. Although several information on genetical work in onion is available in the world but it is very few on $G \times E$ interaction following genetical approach based on first degree statistics.

In Bangladesh, no investigation on $G \times E$ interaction through weighted least square technique has been performed regarding onion. Therefore, the present investigation was undertaken to study $\mathrm{G} \times \mathrm{E}$ interaction on the basis of weighted least square technique for ten bulbs yield contributing traits of two onion varieties in two seasons to investigate the $\mathrm{G} \times \mathrm{E}$ interaction model is adequate or not.

\section{Materials and Methods}

The location of the experimental site is at $24^{\circ} 51$ $\mathrm{N}$ latitude and $89^{\circ} 22^{\prime} \mathrm{E}$ longitude at an elevation of about $18 \mathrm{~m}$ from the average sea level. The experimental field was high land and noncalcareous grey / brown flood plain soils. The soil type was sandy to loam. Organic matter of the soil was $1.1 \%$ with a $\mathrm{pH}$ value of $6.8 \mathrm{~L}$ is situated in Northern Bogra belonging to the Tista Meander Flood Plain which is under Agro-Ecological Zone (AEZ) number 3 (Anonymus, 1988).

The study was conducted at the central farm of Spices Research Center (SRC), Bangladesh Agricultural Research Institute (BARI), Shibgonj, Bogra, Bangladesh. Seeds were sown on May 05 and seedlings were transplanted on June 15, 2005.

Two released onion varieties such as BARI Piaz$2\left(P_{2}\right)$ and BARI Piaz-3 $\left(P_{3}\right)$, their product $F_{1}\left(P_{2} \times\right.$ $\left.P_{3}\right)$ and $F_{2}$ produced in two seasons viz., summer (S) and winter (W) of the year 2005, were the materials in this study. Twenty cross combinations for $F_{1}$ (including reciprocals) bulb production and twenty for $F_{2}$ (including reciprocals) bulb production as well as 5 parents (produced by selfing) of onion were considered as 45 treatments in this trial.

The experiment was set up in a randomized complete block design with three replications. The size of each plot was $3.0 \times 1.0 \mathrm{~m}$. The space between row and plant was $15 \times 10 \mathrm{~cm}$. The treatments were distributed at random within each of the blocks.

Selfing was done by putting individual bamboomade frame with cotton net (20 mesh) over the plants as soon as the first flower opened. Then flies were introduced to ensure pollination. Besides, after anthesis the umbels were rubbed against each other daily for a few days to ensure self-pollination. This rather inexpensive method of selfing is used when only a small quantity of seeds is needed (Jones and Mann, 1963).

Data on ten characters viz., bulb diameter, bulb length, neck diameter, neck length, plant height, number of leaves, leaf length, bulb weight, bulb 
volume and bulb yield /plot were taken from 20 and 25 randomly selected plants for $F_{1}$ and $F_{2}$, respectively. Collected data were analysed through the standard biometrical techniques in the following sub-heads.

\subsection{Detection and estimation of genetic and environmental parameters}

The approach based on fitting models, the specification of the environmental contribution to the phenotypes depending on the experimental design was given by Mather and Jones (1958). It was further extended by Bucio Alanis and Hill (1966b) and Bucio Alanis et al., (1969). Following them, the phenotypic values in a particular environment of the following generation may be written as:

$P_{i j}=\widehat{m}+[d]+e_{j}+g d_{j}$

$P_{2 j}=\widehat{m}-[d]+e_{j}-g d_{j}$

$F_{1 j}=\widehat{m}+[h]+e_{j}+g h_{j}$

$F_{2 j}=\widehat{m}+1 / 2[h]+e_{j}+1 / 2 g h_{j}$

The model was fitted consisting of $\widehat{m},[d],[h], e_{1}$, $\mathrm{gd}_{1}$ and $\mathrm{gh}_{1}$ by weighted least squares and testing its goodness of fit using chi-square $\left(\chi^{2}\right)$ for 2,3 and $4 \mathrm{df}(\mathrm{df}=$ number of generations - number of parameters used). Among the parents and seasons, $\mathrm{P}_{3}$ and winter season were arbitrary and considered as increasing, and those $\mathrm{P}_{2}$ and the summer season was considered as decreasing. The six-parameter $\mathrm{G} \times \mathrm{E}$ interaction model is given Table 1.

\subsection{Estimation of the mean values and standard errors}

Mean: Data on individual plant basis were added together then divided by the total number of observations and the mean was obtained as follows:

$\operatorname{Mean}(\bar{X})=\frac{\sum_{i=1}^{n} X_{i}}{n}$

Where, $X_{i}=$ individual reading recorded from each plant, $\sum X_{i}=$ total number of observations, $n=$ number of observations, $\mathrm{i}=1,2,3, \ldots, \mathrm{n}$ and $\Sigma=$ summation.

Standard error of mean (SE): If several samples are taken, the standard deviations of different samples will vary. These variations are measured by the standard error as follows:

$S E=\sqrt{\frac{S^{2}}{n}}$

Where, $S_{2}=$ variance and $n=$ number of observations.

\subsection{Estimation of $\widehat{m},[d],[h], e, g d_{1}$ and $g_{h}$ and their standard errors}

Estimation of $\widehat{m},[d],[h], e, g_{1}$ and $g_{1}$ and their standard errors by using their co-efficient were calculated as follows:

$$
\begin{aligned}
& \widehat{m}=\frac{1}{8}\left(1 \times \overline{P_{3}}+1 \times \overline{P_{3}}+1 \times \overline{P_{2}}+1 \times \overline{P_{2}}+1 \times \overline{F_{1}}+1 \times \overline{F_{1}}+1 \times \overline{F_{2}}+1 \times \overline{F_{2}}\right) \\
& {[d]=\frac{1}{8}\left(0+0+0+0+1 \times \overline{F_{1}}+1 \times \overline{F_{1}}+1 \times 1 / 2 \overline{F_{2}}+1 \times 1 / 2 \overline{F_{2}}\right)} \\
& {[h]=\frac{1}{8}\left(1 \times \overline{P_{3}}+1 \times \overline{P_{3}}-1 \times \overline{P_{2}}-1 \times \overline{P_{2}}+0+0+0+0\right)} \\
& e=\frac{1}{8}\left(1 \times \overline{P_{3}}-1 \times \overline{P_{3}}+1 \times \overline{P_{2}}-1 \times \overline{P_{2}}+1 \times \overline{F_{1}}-1 \times \overline{F_{1}}+1 \times \overline{F_{2}}-1 \times \overline{F_{2}}\right) \\
& g d_{1}=\frac{1}{8}\left(1 \times \overline{P_{3}}-1 \times \overline{P_{3}}-1 \times \overline{P_{2}}+1 \times \overline{P_{2}}+0+0+0+0\right) \\
& g h_{1}=\frac{1}{8}\left(0+0+0+0+1 \times \overline{F_{1}}-1 \times \overline{F_{1}}+1 \times 1 / 2 \overline{F_{2}}-1 \times 1 / 2 \overline{F_{2}}\right)
\end{aligned}
$$

SE of $\widehat{m},[d],[h], e, g_{1}$ and $g_{1}$

$$
=\sqrt{\frac{1}{64}\left[(S E P 3)^{2}+(S E P 3)^{2}+(S E P 2)^{2}+(S E P 2)^{2}+(S E P 2)^{2}+(S E F 1)^{2}+(S E F 1)^{2}+(S E F 2)^{2}+(S E F 2)^{2}\right]}
$$


Table 1. The six-parameter $\mathrm{G} \times \mathrm{E}$ interaction model

\begin{tabular}{ccccccccc}
\hline \multirow{2}{*}{ Generation } & \multirow{2}{*}{ Season } & \multirow{2}{*}{ Mean } & \multirow{2}{*}{ Variance $\mathrm{W}_{\mathrm{i}=1 / \text { variance }}$} & \multicolumn{5}{c}{ Full Model } \\
\cline { 4 - 8 } & & $\mathrm{W}$ & $\hat{m}$ & {$[\mathrm{~d}]$} & {$[\mathrm{h}]$} & $\mathrm{e}_{1}$ & $\mathrm{gd}_{1}$ & $\mathrm{gh}_{1}$ \\
\hline $\mathrm{P}_{3}$ & $\mathrm{~S}$ & 1 & 1 & 0 & 1 & 1 & 0 \\
$\mathrm{P}_{3}$ & $\mathrm{~W}$ & $\mathrm{~S}$ & 1 & 1 & 0 & -1 & -1 & 0 \\
$\mathrm{P}_{2}$ & $\mathrm{~W}$ & -1 & 0 & 1 & -1 & 0 \\
$\mathrm{P}_{2}$ & $\mathrm{~S}$ & 1 & -1 & 0 & -1 & 1 & 0 \\
$\mathrm{~F}_{1}$ & $\mathrm{~W}$ & 1 & 0 & 1 & 1 & 0 & 1 \\
$\mathrm{~F}_{1}$ & $\mathrm{~S}$ & 1 & 0 & 1 & -1 & 0 & -1 \\
$\mathrm{~F}_{2}$ & $\mathrm{~S}$ & 1 & 0 & $1 / 2$ & 1 & 0 & $1 / 2$ \\
$\mathrm{~F}_{2}$ & $\mathrm{~S}$ & 1 & 0 & $1 / 2$ & -1 & 0 & $-1 / 2$ \\
\hline
\end{tabular}

Where, $\mathrm{W}=$ winter season, $\mathrm{S}=$ summer season, $\mathrm{Wi}=$ weight, $\hat{m}=$ mid parent value, $[\mathrm{d}]=$ additive effects, $[\mathrm{h}]=$ dominance effects, e1= differences between two environments, gd1= measures the interaction between additive and environmental components, and gh1= measures the interaction between dominance and environmental components.

Table 2. The parameters of the goodness of fit

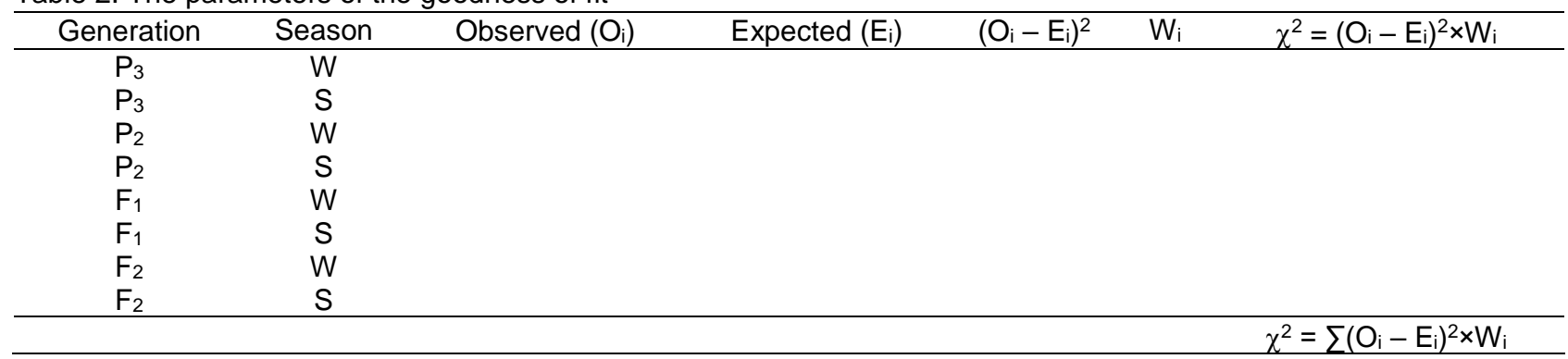

Where, $\mathrm{W}$ = winter season, $\mathrm{S}$ = summer season, $\mathrm{Wi}=$ weight

\subsection{Estimation of expected mean value}

The expected mean value of all generations derived from the estimated values of $\widehat{m}$, [d], [h], $e_{1}$, $\mathrm{gd}_{1}$ and $\mathrm{gh}_{1}$ were calculated as follows:

$M=J^{-1} \times S$

Where, $M=$ estimate of the parameters, $J=$ information matrix, $\mathrm{J}^{-1}=$ inverse of the information matrix and $\mathrm{S}=$ matrix of scores.

After perform the matrix, the expected mean of all generations are as follows:

$\overline{P_{3}}$ in $W=\widehat{m}+[d]+e_{1}+g d_{1}$

$\overline{P_{3}}$ in $S=\widehat{m}+[d]-e_{1}-g d_{1}$

$\overline{P_{2}}$ in $W=\widehat{m}-[d]+e_{1}-g d_{1}$

$\overline{P_{2}}$ in $S=\widehat{m}-[d]-e_{1}+g d_{1}$

$\overline{F_{1}}$ in $W=\widehat{m}+[h]+e_{1}+g h_{1}$

$\overline{F_{1}}$ in $S=\widehat{m}+[h]-e_{1}-g h_{1}$

$\overline{F_{2}}$ in $W=\widehat{m}+1 / 2[h]+e_{1}+1 / 2 g h_{1}$

$\overline{F_{2}}$ in $S=\widehat{m}+1 / 2[h]-e_{1}-1 / 2 g h_{1}$

In case of 4-parameter model for leaf length excluding [d] and $\mathrm{gd}_{1}$ analysis was done. Regarding 5-parameter model for neck length excluding [d] and for number of leaves and bulb volume excluding $\mathrm{gd}_{1}$ analyses were done.

\subsection{Testing the goodness of fit using in 4,5 and 6-parameter $G \times E$ interaction models}

The goodness of fit was tested by using the Table 2. Where the calculated $\chi^{2}$ values were compared with 2, 3 and $4 \mathrm{df}$ depends on how many parameters used in the model. If the $\chi^{2}$ value is significant, it indicates that the $\mathrm{G} \times \mathrm{E}$ interaction model is inadequate and the estimate of the model is biased to an unknown extent. A failure of this model may be attributed to one or more reasons given below (Singh and Pawer, 2005):

(a) The presence of epistasis, that is, the adequacy of the specification of genetic contribution,

(b) Unjustified reduction in the number of environmental parameters, that is, incomplete specification of the environmental contribution, and (c) The presence of $G \times E$ interaction.

\section{Results and Discussion}

The simple additive-dominance model assumes that gene differences contribute independently from one another to variation in the phenotype. The additive-dominance model further assumes that gene differences and environmental differences also contribute independently of one another to variation in the phenotype. We must turn to consider the interaction of gene and environmental differences, how much interaction may arise and how it can be detected, measured and investigated. For the estimation of genotype $\times$ environment $(G \times E)$ interaction in the experiment different seasons in different years and locations are needed. Environmental differences arise due to 
heterogeneity of the environment to which the individuals are distributed. This leads to the difference between both segregating and nonsegregating individuals grown in the same experiment. Specification of the environmental contribution to the phenotype depends on the experimental design, this in turn determines the specification of $G \times E$ interaction.

Mean with standard error in different generations of each variety in two seasons were different for all the ten quantitative characters are presented in Table 3. The mean values show variations from generation to generation in both two varieties and seasons for each of the characters. The maximum mean values for all the characters were obtained for all the generations in winter season. The highest mean was observed in $F_{1}$ generation in winter season for all the characters. Parent $\mathrm{P}_{3}$ in winter season performed better compared to $F_{2}$ with the maximum values of means for all the characters except bulb length. Similar trend was also observed regarding summer season. Comparatively the lowest mean values were recorded in $\mathrm{F}_{2}$ generation in summer season for most of the characters.

The six-parameter $\hat{m},[d],[h], e_{1}, g_{1}, g_{1}$ and their standard errors were estimated and their significant tests of each of the parameters for all the ten quantitative characters were done separately and are presented in Table 4 . Table 4 shows that the values of each parameters for all the characters are significant except $\mathrm{gd}_{1}$ for number of leaves, leaf length and bulb volume and also [d] for neck length and leaf length. Significant $\widehat{m},[d],[h], e_{1}, g_{1} d_{1}$ and $\mathrm{gh}_{1}$ values for bulb diameter, bulb length, neck diameter, plant height, bulb weight and bulb yield/plot indicated the presence of additive and dominance effects and also $G \times E$ interaction. Nonsignificant value of $\mathrm{gd}_{1}$ for number of leaves, leaf length and bulb volume indicated the absence of additive $\times$ environment interaction. Similar analysis in two varieties of Nicotiana rustica was done by Bucio Alanis (1966a) and reported that there was no evidence of $G \times E$ interaction as $\mathrm{gd}_{1}$ found to be non-significant when compared with standard error although there were significant additive genetic [d] and environmental $\left(e_{1}\right)$ effects noted for final plant height. Bucio Alanis (1966a) analyzed the data mean final height of two inbred lines $P_{1}$ and $P_{2}$ of $N$. rustica from the results of an experiment initiated in 1946 by Professor Mather and his colleagues. The experiment was conducted at the John Innes Institute in London from 1946 to 1948, and from 1950 to 1964 at the University of Birmingham and observed that two inbred lines show different responses to the changing environment, although an interpretation of the nature of the different responses $(G \times E)$ is not obvious. Bucio Alanis (1966a) also concluded from generation mean analysis using the same data that genotype $\times$ environmental interaction is linearly related to the environmental effect. On the basis of the $G \times E$ interaction analysis Bucio Alanis (1966a) defining the best genotype as having (a) the highest performance over environments and (b) the highest stability of performance (lowest variance over the possible environments). Overall means ' $m$ ' had the highest magnitude than [d], [h], $e_{1}, g_{1}$ and $g h_{1}$ for all the characters in this investigation. Dominance effect [h] was also higher in magnitude than other parameters regarding all the characters. Environmental effect $e_{1}$ also exhibited higher magnitude than [d], $g_{1}$ and $g_{1}$. The values of additive effect [d] for leaf length and neck length were found to be non-significant although $\mathrm{gd}_{1}$ was significant for neck length. On the other hand, there was no evidence of additive $\times$ environment interaction ' $g d_{1}$ ' for number of leaves, leaf length and bulb volume. The significant values of $\mathrm{gd}_{1}$ indicated the evidence for additive $\times$ environment interaction as well as significant values of $\mathrm{gh}_{1}$ indicated the presence of dominant $\times$ environment interaction.

As the values of [d] and $\mathrm{gd}_{1}$ were found to be non-significant, so, 4-parameter model consisting of $\widehat{m},[\mathrm{~h}], \mathrm{e}_{1}$, and $\mathrm{gh}_{1}$ was considered for leaf length only (Table 5). Five-parameter model consisting of $\widehat{m}$, [d], [h], $e_{1}$, and $\mathrm{gh}_{1}$ was considered for number of leaves and bulb volume (Table 5). Another 5parameter model consisting of $\hat{m},[\mathrm{~h}], \mathrm{e}_{1}, \mathrm{gd}_{1}$ and $g \mathrm{~h}_{1}$ was used for neck length (Table 5). Six-parameter model (Table 5) consisting of $\widehat{m},[\mathrm{~d}],[\mathrm{h}], \mathrm{e}_{1}, \mathrm{gd}_{1}$ and $\mathrm{gh}_{1}$ was considered for the rest of six traits as all the parameters were found to be significant for these characters.

Chi-square $\left(x^{2}\right)$ testing of goodness of fit of model including four-parameter for one character, five-parameter for three characters and sixparameter for the rest six quantitative characters with two varieties of onion in two seasons were done separately and are shown in Table 5 . This table showed that all of the four, five and sixparameter models were not adequate as indicated by their significant $X^{2}(4), X^{2}(3)$ and $X^{2}$ (2) values for all the characters except for neck length and bulb length. Similar trend of results in two and three parameters models were found by Azad (1991) in lentil. Researcher also reported that in case of 4parameter model, the non-significant $X^{2}$ values for all the six characters indicated the adequacy of $G \times E$ interaction model. Genetical approach of $G \times E$ interaction model based on first degree statistics was also explained by Mather and Jones (1958) and gave specifications of various phenotypes in terms of biometrical genetic parameters. Bucio Alanis (1966a) developed a biometrical genetic model to explain the $G \times E$ interaction and applied this model to Nicotiana rustica data on two inbred lines grown at two different locations over 16 years and observed the linear relationship between the environmental effect and $G \times E$ interaction. Bucio Alanis and Hill (1966b) extended of Bucio Alanis (1966a) model to include heterozygote and applied it to $N$. rustica data and again observed the similar result of Bucio Alanis 
Table 3. Mean values with standard error (SE) and their weight $\left(\mathrm{W}_{\mathrm{i}}\right)$ of four generations of ten bulb yield contributing traits in onion

\begin{tabular}{|c|c|c|c|c|c|}
\hline \multirow{2}{*}{ Generations } & \multirow{2}{*}{ Season } & Mean \pm SE & $\mathrm{W}_{\mathrm{i}}$ & Mean \pm SE & $\mathrm{W}_{\mathrm{i}}$ \\
\hline & & Bulb diameter & & \multicolumn{2}{|c|}{ Bulb length (cm) } \\
\hline$P_{3}$ & W & $4.3067 \pm 0.0287$ & 20.2225 & $4.8783 \pm 0.0233$ & 30.7031 \\
\hline$P_{3}$ & $S$ & $3.5333 \pm 0.0172$ & 56.0224 & $4.6333 \pm 0.0234$ & 30.5158 \\
\hline $\mathrm{P}_{2}$ & W & $4.1450 \pm 0.0227$ & 32.2685 & $5.0133 \pm 0.0251$ & 26.4620 \\
\hline $\mathrm{P}_{2}$ & $S$ & $3.0333 \pm 0.0169$ & 58.2072 & $5.0667 \pm 0.0229$ & 31.837 \\
\hline $\mathrm{F}_{1}$ & W & $4.7117 \pm 0.0293$ & 19.3949 & $6.0033 \pm 0.0273$ & 22.3564 \\
\hline$F_{1}$ & $S$ & $3.4333 \pm 0.0207$ & 38.9864 & $5.4167 \pm 0.0347$ & 13.8408 \\
\hline $\mathrm{F}_{2}$ & W & $3.9867 \pm 0.0340$ & 11.5500 & $5.0133 \pm 0.1139$ & 1.0280 \\
\hline \multirow[t]{2}{*}{$\mathrm{F}_{2}$} & $\mathrm{~S}$ & $2.6367 \pm 0.0412$ & 9.8348 & $4.3667 \pm 0.0550$ & 5.5072 \\
\hline & & \multicolumn{2}{|c|}{ Neck diameter $(\mathrm{cm})$} & \multicolumn{2}{|c|}{ Neck length (cm) } \\
\hline $\mathrm{P}_{3}$ & W & $0.8367 \pm 0.0100$ & 164.2036 & $1.8667 \pm 0.0171$ & 57.1102 \\
\hline $\mathrm{P}_{3}$ & $S$ & $0.7333 \pm 0.0116$ & 124.6883 & $1.4500 \pm 0.0140$ & 85.5432 \\
\hline $\mathrm{P}_{2}$ & W & $0.9117 \pm 0.0109$ & 139.8601 & $1.7200 \pm 0.0109$ & 64.3915 \\
\hline $\mathrm{P}_{2}$ & $S$ & $0.5700 \pm 0.0073$ & 265.2520 & $1.5183 \pm 0.0191$ & 45.7457 \\
\hline $\mathrm{F}_{1}$ & W & $1.1083 \pm 0.0139$ & 86.0585 & $2.000 \pm 0.0165$ & 61.4628 \\
\hline $\mathrm{F}_{1}$ & $S$ & $0.8633 \pm 0.0110$ & 137.3626 & $1.6000 \pm 0.0249$ & 26.8168 \\
\hline $\mathrm{F}_{2}$ & W & $0.8987 \pm 0.0194$ & 15.4108 & $1.2080 \pm 0.0351$ & 10.8260 \\
\hline \multirow[t]{2}{*}{$\mathrm{F}_{2}$} & $\mathrm{~S}$ & $0.7667 \pm 0.0153$ & 70.8215 & $1.5667 \pm 0.0572$ & 5.1245 \\
\hline & & \multicolumn{2}{|c|}{ Plant height $(\mathrm{cm})$} & \multicolumn{2}{|c|}{ Number of leaves } \\
\hline $\mathrm{P}_{3}$ & $\mathrm{~W}$ & $47.2167 \pm 0.0792$ & 2.6596 & $5.8333 \pm 0.1041$ & 1.5391 \\
\hline $\mathrm{P}_{3}$ & $\mathrm{~S}$ & $35.5000 \pm 0.0770$ & 2.8095 & $5.700 \pm 0.1017$ & 1.6121 \\
\hline $\mathrm{P}_{2}$ & W & $42.3333 \pm 0.0614$ & 4.4250 & $5.6667 \pm 0.0812$ & 2.5286 \\
\hline $\mathrm{P}_{2}$ & $S$ & $31.8833 \pm 0.1065$ & 1.4683 & $5.1500 \pm 0.0884$ & 2.1338 \\
\hline$F_{1}$ & W & $47.4667 \pm 0.0805$ & 2.5727 & $6.3000 \pm 0.1147$ & 1.2661 \\
\hline$F_{1}$ & $\mathrm{~S}$ & $35.8667 \pm 0.1268$ & 1.0363 & $5.8000 \pm 0.0974$ & 1.7560 \\
\hline $\mathrm{F}_{2}$ & W & $42.3733 \pm 0.3071$ & 0.1413 & $5.6400 \pm 0.1180$ & 0.9576 \\
\hline \multirow[t]{2}{*}{$\mathrm{F}_{2}$} & $\mathrm{~S}$ & $30.2667 \pm 0.4522$ & 0.0813 & $5.0000 \pm 0.1188$ & 1.1800 \\
\hline & & \multicolumn{2}{|c|}{ Leaf length $(\mathrm{cm})$} & \multicolumn{2}{|c|}{ Bulb weight (gm) } \\
\hline $\mathrm{P}_{3}$ & W & $36.3333 \pm 0.1227$ & 1.1063 & $30.6667 \pm 0.0999$ & 1.6698 \\
\hline $\mathrm{P}_{3}$ & $S$ & $23.6333 \pm 0.1188$ & 1.1816 & $20.1667 \pm 0.1191$ & 1.3308 \\
\hline $\mathrm{P}_{2}$ & W & $35.5000 \pm 0.0905$ & 2.0345 & $29.2167 \pm 0.1092$ & 1.3987 \\
\hline $\mathrm{P}_{2}$ & $S$ & $19.9167 \pm 0.1172$ & 1.2144 & $18.4000 \pm 0.1145$ & 1.2716 \\
\hline $\mathrm{F}_{1}$ & W & $37.3333 \pm 0.1133$ & 1.2107 & $31.0833 \pm 0.1122$ & 1.3234 \\
\hline $\mathrm{F}_{1}$ & $S$ & $25.3333 \pm 0.1132$ & 1.3015 & $20.7500 \pm 0.1026$ & 1.5839 \\
\hline $\mathrm{F}_{2}$ & W & $33.8533 \pm 0.3875$ & 0.0888 & $27.9733 \pm 0.3013$ & 0.1468 \\
\hline \multirow[t]{2}{*}{$\mathrm{F}_{2}$} & $\mathrm{~S}$ & $24.0333 \pm 0.2820$ & 0.2063 & $18.3333 \pm 0.2466$ & 0.2774 \\
\hline & & \multicolumn{2}{|c|}{ Bulb yield plot ${ }^{-1}$} & \multicolumn{2}{|c|}{ Bulb volume $\left(\mathrm{cm}^{3}\right)$} \\
\hline $\mathrm{P}_{3}$ & W & $7.6333 \pm 0.0263$ & 24.0500 & $17.0000 \pm 0.1438$ & 1.6110 \\
\hline $\mathrm{P}_{3}$ & $\mathrm{~S}$ & $5.0333 \pm 0.0344$ & 14.0706 & $14.6667 \pm 0.3333$ & 0.6000 \\
\hline $\mathrm{P}_{2}$ & W & $7.3400 \pm 0.0289$ & 19.9045 & $16.3333 \pm 0.1541$ & 1.4030 \\
\hline $\mathrm{P}_{2}$ & $S$ & $4.2660 \pm 0.0251$ & 26.4201 & $13.400 \pm 0.2350$ & 1.2069 \\
\hline $\mathrm{F}_{1}$ & W & $7.7100 \pm 0.0271$ & 22.5648 & $21.3333 \pm 0.1465$ & 1.5536 \\
\hline $\mathrm{F}_{1}$ & $S$ & $5.2133 \pm 0.0351$ & 13.5648 & $15.6667 \pm 0.2108$ & 1.5000 \\
\hline $\mathrm{F}_{2}$ & W & $6.9733 \pm 0.0390$ & 8.7819 & $16.0000 \pm 0.4180$ & 0.1908 \\
\hline $\mathrm{F}_{2}$ & $S$ & $4.6267 \pm 0.0612$ & 4.4571 & $13.6667 \pm 0.3737$ & 0.4773 \\
\hline
\end{tabular}

$\mathrm{W}=$ winter season, $\mathrm{S}=$ summer season

Table 4. Estimated values of $\widehat{m},[\mathrm{~d}],[\mathrm{h}], \mathrm{e}, \mathrm{gd}_{1}$ and $\mathrm{gh}_{1}$ and their standard error from 6-parameter model of ten bulb yield contributing traits in onion

\begin{tabular}{|c|c|c|c|c|c|c|c|}
\hline Characters & $\widehat{m}$ & [d] & [h] & $e_{1}$ & $\operatorname{gd}_{1}$ & $\mathrm{gh}_{1}$ & Standard error \\
\hline Bulb diameter & $3.7233^{*}$ & $0.0827^{*}$ & $1.4321^{*}$ & $0.5642^{*}$ & $-0.0423^{*}$ & $0.2442^{*}$ & 0.0097 \\
\hline Bulb length & $5.0490^{\star}$ & $-0.0710^{*}$ & $2.0138^{*}$ & $0.1782^{\star}$ & $0.0373^{\star}$ & $0.1137^{*}$ & 0.0178 \\
\hline Neck diameter & $0.8361^{*}$ & $0.0110^{*}$ & $0.3505^{\star}$ & $0.1028^{\star}$ & $-0.0298^{*}$ & $0.0389^{*}$ & 0.0046 \\
\hline Neck length & $1.6162^{*}$ & $0.0098^{\mathrm{NS}}$ & $0.6234^{*}$ & $0.0825^{*}$ & $0.0269^{*}$ & $0.0276^{*}$ & 0.0101 \\
\hline Plant height & $39.1133^{*}$ & $1.0625^{*}$ & $14.9567^{*}$ & $5.7342^{\star}$ & $0.15833^{*}$ & $2.2066^{*}$ & 0.0740 \\
\hline Number of leaves & $5.6363^{*}$ & $0.0896^{*}$ & $2.1775^{*}$ & $0.2238^{*}$ & $-0.0479^{N S}$ & $0.1025^{*}$ & 0.0367 \\
\hline Leaf length & $29.4921^{*}$ & $0.0544^{N S}$ & $1.2061^{*}$ & $0.7749^{\star}$ & $0.0487^{N S}$ & $0.4082^{*}$ & 0.0693 \\
\hline Bulb weight & $24.5738^{*}$ & $0.4021^{*}$ & $9.3733^{*}$ & $5.1613^{*}$ & $0.8359^{*}$ & $1.8942^{*}$ & 0.0591 \\
\hline Bulb yield plot ${ }^{-1}$ & $6.0996^{\star}$ & $0.1325^{*}$ & $2.3404^{*}$ & $1.3146^{*}$ & $0.7072^{*}$ & $0.4588^{*}$ & 0.0128 \\
\hline Bulb volume & $16.0083^{*}$ & $0.2417^{*}$ & $6.4792^{*}$ & $1.6583^{*}$ & $-0.075^{N S}$ & $0.8542^{*}$ & 0.0961 \\
\hline
\end{tabular}

${ }^{*}$ and NS indicate significant and non-signifiant, respectively. 
Deb and Ara / HortiS (2021) 38(2):62-70

Table 5. Chi-square (x2) values following 6, 5, and 4-parameter models of ten bulb yield contributing traits in onion Bulb diameter (cm)

\begin{tabular}{|c|c|c|c|c|c|c|c|c|c|c|c|}
\hline Generations & Mean & $\widehat{m}$ & $d$ & $\mathrm{~h}$ & $\mathrm{e}$ & $\mathrm{gd}$ & gh & Expected mean & $\mathrm{Wi}$ & $\left(\mathrm{O}_{i}-\mathrm{E}_{\mathrm{i}}\right)^{2}$ & $\mathrm{~W}_{\mathrm{i}} \times\left(\mathrm{O}_{\mathrm{i}}-\mathrm{E}_{\mathrm{i}}\right)^{2}$ \\
\hline$P_{3}$ & 4.3067 & 1 & 1 & 0 & 1 & 1 & 0 & 4.2788 & 20.2225 & 0.0008 & 0.0158 \\
\hline$P_{3}$ & 3.5333 & 1 & 1 & 0 & -1 & -1 & 0 & 3.4933 & 56.0224 & 0.0016 & 0.0894 \\
\hline $\mathrm{P}_{2}$ & 4.1450 & 1 & -1 & 0 & 1 & -1 & 0 & 4.1275 & 32.2685 & 0.0003 & 0.0099 \\
\hline $\mathrm{P}_{2}$ & 3.0333 & 1 & -1 & 0 & -1 & 1 & 0 & 2.9948 & 58.2072 & 0.0015 & 0.0864 \\
\hline $\mathrm{F}_{1}$ & 4.7117 & 1 & 0 & 1 & 1 & 0 & 1 & 4.5896 & 19.3949 & 0.0149 & 0.2890 \\
\hline $\mathrm{F}_{1}$ & 3.4333 & 1 & 0 & 1 & -1 & 0 & -1 & 3.3501 & 38.9864 & 0.0069 & 0.2701 \\
\hline $\mathrm{F}_{2}$ & 3.9867 & 1 & 0 & $1 / 2$ & 1 & 0 & $1 / 2$ & 4.3964 & 11.5500 & 0.1678 & 1.9384 \\
\hline $\mathrm{F}_{2}$ & 2.6367 & 1 & 0 & $1 / 2$ & -1 & 0 & $-1 / 2$ & 3.2971 & 9.8348 & 0.4361 & 4.2887 \\
\hline \multicolumn{12}{|c|}{$\sum \chi^{2}(2)=6.9876^{*}$} \\
\hline \multicolumn{12}{|c|}{ Bulb length (cm) } \\
\hline Generations & Mean & $\widehat{m}$ & $\mathrm{~d}$ & $\mathrm{~h}$ & e & $\mathrm{gd}$ & gh & Expected mean & Wi & $\left(\mathrm{O}_{i}-\mathrm{E}_{\mathrm{i}}\right)^{2}$ & $\mathrm{~W}_{\mathrm{i}} \times\left(\mathrm{O}_{\mathrm{i}}-\mathrm{E}_{\mathrm{i}}\right)^{2}$ \\
\hline$P_{3}$ & 4.8783 & 1 & 1 & 0 & 1 & 1 & 0 & 4.8746 & 30.7031 & 1.4255 & 0.0004 \\
\hline$P_{3}$ & 4.6333 & 1 & 1 & 0 & -1 & -1 & 0 & 4.6025 & 30.5157 & 0.00095 & 0.0291 \\
\hline $\mathrm{P}_{2}$ & 5.0133 & 1 & -1 & 0 & 1 & -1 & 0 & 5.0089 & 26.4620 & 1.9279 & 0.0005 \\
\hline $\mathrm{P}_{2}$ & 5.0667 & 1 & -1 & 0 & -1 & 1 & 0 & 5.0372 & 31.8370 & 0.00087 & 0.0277 \\
\hline $\mathrm{F}_{1}$ & 6.0033 & 1 & 0 & 1 & 1 & 0 & 1 & 5.9929 & 22.3564 & 0.00011 & 0.0024 \\
\hline $\mathrm{F}_{1}$ & 5.4167 & 1 & 0 & 1 & -1 & 0 & -1 & 5.2807 & 13.8408 & 0.0185 & 0.2558 \\
\hline $\mathrm{F}_{2}$ & 5.0133 & 1 & 0 & $1 / 2$ & 1 & 0 & $1 / 2$ & 5.4673 & 1.0280 & 0.2061 & 0.2119 \\
\hline $\mathrm{F}_{2}$ & 4.3667 & 1 & 0 & $1 / 2$ & -1 & 0 & $-1 / 2$ & 5.0503 & 5.5072 & 0.4673 & 2.5735 \\
\hline \multirow{2}{*}{\multicolumn{12}{|c|}{$\sum \chi^{2}(2)=3.1013^{N S}$}} \\
\hline & & & & & & & & & & & \\
\hline Generations & Mean & $\widehat{m}$ & $\mathrm{~d}$ & $\mathrm{~h}$ & $\mathrm{e}$ & $\mathrm{gd}$ & gh & Expected mean & $\mathrm{Wi}$ & $\left(\mathrm{O}_{i}-\mathrm{E}_{\mathrm{i}}\right)^{2}$ & $\mathrm{~W}_{\mathrm{i}} \times\left(\mathrm{O}_{\mathrm{i}}-\mathrm{E}_{\mathrm{i}}\right)^{2}$ \\
\hline$P_{3}$ & 0.8367 & 1 & 1 & 0 & 1 & 1 & 0 & 0.5543 & 164.2036 & 0.0797 & 13.0882 \\
\hline$P_{3}$ & 0.7333 & 1 & 1 & 0 & -1 & -1 & 0 & 1.5665 & 124.6883 & 0.6942 & 86.5628 \\
\hline $\mathrm{P}_{2}$ & 0.9117 & 1 & -1 & 0 & 1 & -1 & 0 & 0.5628 & 139.8601 & 0.1217 & 17.0230 \\
\hline$P_{2}$ & 0.5700 & 1 & -1 & 0 & -1 & 1 & 0 & 0.9735 & 265.252 & 0.1628 & 43.1862 \\
\hline $\mathrm{F}_{1}$ & 1.1083 & 1 & 0 & 1 & 1 & 0 & 1 & 1.1205 & 86.05852 & 0.0001 & 0.0128 \\
\hline $\mathrm{F}_{1}$ & 0.8633 & 1 & 0 & 1 & -1 & 0 & -1 & 0.7949 & 137.3626 & 0.0047 & 0.6431 \\
\hline $\mathrm{F}_{2}$ & 0.8987 & 1 & 0 & $1 / 2$ & 1 & 0 & $1 / 2$ & 0.8395 & 35.4107 & 0.0035 & 0.1238 \\
\hline $\mathrm{F}_{2}$ & 0.7667 & 1 & 0 & $1 / 2$ & -1 & 0 & $-1 / 2$ & 1.0325 & 70.8215 & 0.0706 & 5.0033 \\
\hline \multirow{2}{*}{\multicolumn{12}{|c|}{$\sum \chi^{2}(2)=165.6432^{* \star *}$}} \\
\hline & & & & & & & & & & & \\
\hline Generations & Mean & $\widehat{m}$ & $d$ & $\mathrm{~h}$ & $\mathrm{e}$ & $\mathrm{gd}$ & gh & Expected mean & $\mathrm{Wi}$ & $\left(\mathrm{O}_{i}-\mathrm{E}_{\mathrm{i}}\right)^{2}$ & $\overline{W_{i} \times\left(O_{i}-E_{i}\right)^{2}}$ \\
\hline$P_{3}$ & 47.2167 & 1 & 1 & 0 & 1 & 1 & 0 & 48.7240 & 2.6596 & 2.2719 & 6.0424 \\
\hline $\mathrm{P}_{3}$ & 35.5000 & 1 & 1 & 0 & -1 & -1 & 0 & 45.7121 & 2.8095 & 104.287 & 292.9973 \\
\hline $\mathrm{P}_{2}$ & 42.3333 & 1 & -1 & 0 & 1 & -1 & 0 & 43.5870 & 4.4249 & 1.5718 & 6.9553 \\
\hline $\mathrm{P}_{2}$ & 31.8833 & 1 & -1 & 0 & -1 & 1 & 0 & 42.5989 & 1.4683 & 114.824 & 168.5940 \\
\hline$F_{1}$ & 47.4667 & 1 & 0 & 1 & 1 & 0 & 1 & 47.3257 & 2.5727 & 0.0199 & 0.0512 \\
\hline $\mathrm{F}_{1}$ & 35.8667 & 1 & 0 & 1 & -1 & 0 & -1 & 42.9163 & 1.0363 & 49.6971 & 51.5011 \\
\hline $\mathrm{F}_{2}$ & 42.3733 & 1 & 0 & $1 / 2$ & 1 & 0 & $1 / 2$ & 46.7406 & 0.1413 & 19.0732 & 2.6958 \\
\hline $\mathrm{F}_{2}$ & 30.2667 & 1 & 0 & $1 / 2$ & -1 & 0 & $-1 / 2$ & 43.5359 & 0.0815 & 176.073 & 14.3534 \\
\hline
\end{tabular}

$\sum \chi^{2}(2)=543.1905^{* \star *}$

\begin{tabular}{|c|c|c|c|c|c|c|c|c|c|c|c|}
\hline \multicolumn{12}{|c|}{ Bulb weight $(\mathrm{g})$} \\
\hline Generations & Mean & $\widehat{m}$ & $\mathrm{~d}$ & $\mathrm{~h}$ & $\mathrm{e}$ & gd & gh & Expected mean & $\mathrm{W}_{\mathrm{i}}$ & $\left(O_{i}-E_{i}\right)^{2}$ & $\mathrm{~W}_{\mathrm{i}} \times\left(\mathrm{O}_{\mathrm{i}}-\mathrm{E}_{\mathrm{i}}\right)^{2}$ \\
\hline$P_{3}$ & 30.6667 & 1 & 1 & 0 & 1 & 1 & 0 & 30.4644 & 1.6698 & 0.0409 & 0.0683 \\
\hline$P_{3}$ & 20.1667 & 1 & 1 & 0 & -1 & -1 & 0 & 20.2394 & 1.3308 & 0.0053 & 0.0070 \\
\hline $\mathrm{P}_{2}$ & 29.2167 & 1 & -1 & 0 & 1 & -1 & 0 & 29.5815 & 1.3987 & 0.1331 & 0.1862 \\
\hline $\mathrm{P}_{2}$ & 18.4000 & 1 & -1 & 0 & -1 & 1 & 0 & 17.8863 & 1.2716 & 0.2639 & 0.3356 \\
\hline $\mathrm{F}_{1}$ & 31.0833 & 1 & 0 & 1 & 1 & 0 & 1 & 31.1234 & 1.3234 & 0.0016 & 0.0021 \\
\hline $\mathrm{F}_{1}$ & 20.7500 & 1 & 0 & 1 & -1 & 0 & -1 & 20.5051 & 1.5839 & 0.0600 & 0.0950 \\
\hline $\mathrm{F}_{2}$ & 27.9733 & 1 & 0 & $1 / 2$ & 1 & 0 & $1 / 2$ & 30.5732 & 0.1468 & 6.7595 & 0.9923 \\
\hline $\mathrm{F}_{2}$ & 18.3333 & 1 & 0 & $1 / 2$ & -1 & 0 & $-1 / 2$ & 25.2640 & 0.2740 & 48.0351 & 13.1616 \\
\hline
\end{tabular}

Bulb yield plot $^{-1}$

\begin{tabular}{clllllllrrrr}
\hline Generations & Mean & $\widehat{m}$ & $\mathrm{~d}$ & $\mathrm{~h}$ & $\mathrm{e}$ & $\mathrm{gd}$ & $\mathrm{gh}$ & Expected mean & \multicolumn{1}{c}{$\mathrm{W}_{\mathrm{i}}$} & $\left(\mathrm{O}_{\mathrm{i}}-\mathrm{E}_{\mathrm{i}}\right)^{2}$ & $\mathrm{~W}_{\mathrm{i}} \times\left(\mathrm{O}_{\mathrm{i}}-\mathrm{E}_{\mathrm{i}}\right)^{2}$ \\
\hline $\mathrm{P}_{3}$ & 7.6333 & 1 & 1 & 0 & 1 & 1 & 0 & 8.6115 & 24.0500 & 0.9567 & 23.0096 \\
$\mathrm{P}_{3}$ & 5.0333 & 1 & 1 & 0 & -1 & -1 & 0 & 4.9182 & 14.0710 & 0.0132 & 0.1864 \\
$\mathrm{P}_{2}$ & 7.3400 & 1 & -1 & 0 & 1 & -1 & 0 & 2.9013 & 19.9045 & 19.7024 & 392.1654 \\
$\mathrm{P}_{2}$ & 4.2666 & 1 & -1 & 0 & -1 & 1 & 0 & 0.3045 & 26.4201 & 15.6986 & 414.7591 \\
$\mathrm{~F}_{1}$ & 7.7100 & 1 & 0 & 1 & 1 & 0 & 1 & 7.7524 & 22.5648 & 0.0018 & 0.0407 \\
$\mathrm{~F}_{1}$ & 5.2133 & 1 & 0 & 1 & -1 & 0 & -1 & 5.3217 & 13.5648 & 0.0117 & 0.1592 \\
$\mathrm{~F}_{2}$ & 6.9733 & 1 & 0 & $1 / 2$ & 1 & 0 & $1 / 2$ & 6.7544 & 8.7819 & 0.0479 & 0.4209 \\
$\mathrm{~F}_{2}$ & 4.6267 & 1 & 0 & $1 / 2$ & -1 & 0 & $-1 / 2$ & 3.9665 & 4.4571 & 0.4358 & 1.9424 \\
\hline
\end{tabular}


Deb and Ara / HortiS (2021) 38(2):62-70

Table 5. Chi-square (x2) values following 6, 5, and 4-parameter models of ten bulb yield contributing traits in onion (cont.)

\begin{tabular}{|c|c|c|c|c|c|c|c|c|c|c|}
\hline \multicolumn{11}{|c|}{ Neck length $(\mathrm{cm})$} \\
\hline Generations & Mean & $\widehat{m}$ & $\mathrm{~h}$ & $\mathrm{e}$ & $\mathrm{gd}$ & gh & Expected mean & $\mathrm{W}_{\mathrm{i}}$ & $\left(O_{i}-E_{i}\right)^{2}$ & $\mathrm{~W}_{\mathrm{i}} \times\left(\mathrm{O}_{\mathrm{i}}-\mathrm{E}_{\mathrm{i}}\right)^{2}$ \\
\hline $\mathrm{P}_{3}$ & 1.8667 & 1 & 0 & 1 & 1 & 0 & 1.8174 & 57.1102 & 0.0024 & 0.1387 \\
\hline $\mathrm{P}_{3}$ & 1.4500 & 1 & 0 & -1 & -1 & 0 & 1.4317 & 85.5432 & 0.0003 & 0.0285 \\
\hline $\mathrm{P}_{2}$ & 1.7200 & 1 & 0 & 1 & -1 & 0 & 1.7115 & 64.3915 & 0.0001 & 0.0047 \\
\hline $\mathrm{P}_{2}$ & 1.5183 & 1 & 0 & -1 & 1 & 0 & 1.5376 & 45.7457 & 0.0004 & 0.0170 \\
\hline $\mathrm{F}_{1}$ & 2.0000 & 1 & 1 & 1 & 0 & 1 & 1.9431 & 61.4628 & 0.0032 & 0.1991 \\
\hline $\mathrm{F}_{1}$ & 1.6000 & 1 & 1 & -1 & 0 & -1 & 1.6023 & 26.8168 & 0.0000 & 0.0001 \\
\hline $\mathrm{F}_{2}$ & 1.2080 & 1 & $1 / 2$ & 1 & 0 & $1 / 2$ & 1.8538 & 10.8260 & 0.4170 & 4.5145 \\
\hline $\mathrm{F}_{2}$ & 1.5667 & 1 & $1 / 2$ & -1 & 0 & $-1 / 2$ & 1.5435 & 5.1245 & 0.0005 & 0.0028 \\
\hline \multirow{2}{*}{\multicolumn{11}{|c|}{$\sum \chi^{2}(3)=4.9054^{\mathrm{NS}}$}} \\
\hline & & & & & & & & & & \\
\hline Generations & Mean & $\widehat{m}$ & $d$ & $\mathrm{~h}$ & $\mathrm{e}$ & gh & Expected mean & $\overline{W_{i}}$ & $\left(\mathrm{O}_{i}-\mathrm{E}_{\mathrm{i}}\right)^{2}$ & $\mathrm{~W}_{\mathrm{i}} \times\left(\mathrm{O}_{\mathrm{i}}-\mathrm{E}_{\mathrm{i}}\right)^{2}$ \\
\hline $\mathrm{P}_{3}$ & 5.8333 & 1 & 1 & 0 & 1 & 0 & -11.9707 & 1.5391 & 316.9833 & 487.8690 \\
\hline $\mathrm{P}_{3}$ & 5.7000 & 1 & 1 & 0 & -1 & 0 & 23.1158 & 1.6121 & 303.3110 & 488.9677 \\
\hline $\mathrm{P}_{2}$ & 5.6667 & 1 & -1 & 0 & 1 & 0 & -11.9695 & 2.5286 & 311.0364 & 786.4868 \\
\hline $\mathrm{P}_{2}$ & 5.1500 & 1 & -1 & 0 & -1 & 0 & 23.1170 & 2.1338 & 322.8129 & 688.8182 \\
\hline $\mathrm{F}_{1}$ & 6.3000 & 1 & 0 & 1 & 1 & 1 & -7.5799 & 1.2661 & 192.6514 & 243.9159 \\
\hline $\mathrm{F}_{1}$ & 5.8000 & 1 & 0 & 1 & -1 & -1 & 19.4376 & 1.756 & 185.9853 & 326.5902 \\
\hline $\mathrm{F}_{2}$ & 5.6400 & 1 & 0 & $1 / 2$ & 1 & $1 / 2$ & -9.7750 & 0.9576 & 237.6222 & 227.5471 \\
\hline $\mathrm{F}_{2}$ & 5.0000 & 1 & 0 & $1 / 2$ & -1 & $-1 / 2$ & 21.2770 & 1.1800 & 264.9416 & 312.6311 \\
\hline \multirow{2}{*}{\multicolumn{11}{|c|}{$\sum \chi^{2}(3)=3562.8260^{* *+}$}} \\
\hline & & & & & & & & & & \\
\hline Generations & Mean & $\widehat{m}$ & $\mathrm{~d}$ & $\mathrm{~h}$ & $\mathrm{e}$ & gh & Expected mean & $\mathrm{W}_{\mathrm{i}}$ & $\left(\mathrm{O}_{i}-\mathrm{E}_{\mathrm{i}}\right)^{2}$ & $\mathrm{~W}_{\mathrm{i}} \times\left(\mathrm{O}_{\mathrm{i}}-\mathrm{E}_{\mathrm{i}}\right)^{2}$ \\
\hline$P_{3}$ & 17.0000 & 1 & 1 & 0 & 1 & 0 & 16.3607 & 1.6111 & 0.4087 & 0.6584 \\
\hline$P_{3}$ & 14.6667 & 1 & 1 & 0 & -1 & 0 & 16.4803 & 0.600 & 3.2892 & 1.9735 \\
\hline$P_{2}$ & 16.3330 & 1 & -1 & 0 & 1 & 0 & 14.7641 & 1.4032 & 2.4616 & 3.4542 \\
\hline $\mathrm{P}_{2}$ & 13.4000 & 1 & -1 & 0 & -1 & 0 & 14.8836 & 1.2069 & 2.2012 & 2.6566 \\
\hline $\mathrm{F}_{1}$ & 21.3333 & 1 & 0 & 1 & 1 & 1 & 21.1874 & 1.5536 & 0.0213 & 0.0331 \\
\hline $\mathrm{F}_{1}$ & 15.6670 & 1 & 0 & 1 & -1 & -1 & 15.3707 & 1.5000 & 0.0876 & 0.1314 \\
\hline $\mathrm{F}_{2}$ & 16.0000 & 1 & 0 & $1 / 2$ & 1 & $1 / 2$ & 18.3749 & 0.1908 & 5.6402 & 1.0761 \\
\hline $\mathrm{F}_{2}$ & 13.6667 & 1 & 0 & $1 / 2$ & -1 & $-1 / 2$ & 15.5264 & 0.4773 & 3.4583 & 1.6506 \\
\hline \multirow{2}{*}{\multicolumn{11}{|c|}{$\sum \chi^{2}(3)=11.6339^{* *}$}} \\
\hline & & & & & & & & & & \\
\hline Generations & Mean & $\widehat{m}$ & & $\mathrm{~h}$ & $\mathrm{e}$ & gh & Expected mean & $\mathrm{W}_{\mathrm{i}}$ & $\left(\mathrm{O}_{i}-\mathrm{E}_{\mathrm{i}}\right)^{2}$ & $\mathrm{~W}_{\mathrm{i}} \times\left(\mathrm{O}_{\mathrm{i}}-\mathrm{E}_{\mathrm{i}}\right)^{2}$ \\
\hline$P_{3}$ & 36.3333 & 1 & & 0 & 1 & 0 & 27.74277 & 1.1063 & 73.7973 & 81.6419 \\
\hline$P_{3}$ & 23.6333 & 1 & & 0 & -1 & 0 & 31.40086 & 1.1816 & 60.3345 & 71.2913 \\
\hline $\mathrm{P}_{2}$ & 35.5000 & 1 & & 0 & 1 & 0 & 27.74277 & 2.0345 & 60.1747 & 122.4253 \\
\hline$P_{2}$ & 19.9167 & 1 & & 0 & -1 & 0 & 31.40086 & 1.2144 & 131.8866 & 160.1631 \\
\hline $\mathrm{F}_{1}$ & 37.3333 & 1 & & 1 & 1 & 1 & 37.12479 & 1.2107 & 0.0435 & 0.0526 \\
\hline $\mathrm{F}_{1}$ & 25.3333 & 1 & & 1 & -1 & -1 & 25.13640 & 1.3015 & 0.0388 & 0.0505 \\
\hline $\mathrm{F}_{2}$ & 33.8533 & 1 & & $1 / 2$ & 1 & $1 / 2$ & 32.43378 & 0.0888 & 2.0151 & 0.1789 \\
\hline $\mathrm{F}_{2}$ & 24.0333 & 1 & & $1 / 2$ & -1 & $-1 / 2$ & 28.26863 & 0.2063 & 17.9378 & 3.7006 \\
\hline
\end{tabular}

${ }^{*},{ }^{* *},{ }^{* * *}$, and NS indicate significant at $5 \%, 1 \%, 0.1 \%$ level, and non-significant, respectively.

(1966a) that found earlier. Bucio Alanis et al. (1969) further extended this $G \times E$ interaction model to include $F_{2}$ and backcross generations in the analysis and predicted the relationship between potence, heterosis and additive environmental effects (Singh and Pawar, 2005). To determine the stability and adaptability performance of onion, statistical approach of $\mathrm{G} \times \mathrm{E}$ interaction model was also performed by Golani et al. (2005), Jokanovic et al. (2016), and Tahir et al. (2020). Results of the present investigation shows that out of the ten characters only for neck length and bulb length with the genetic and environmental effects, $G \times E$ interaction effect is also present due to adequate of $G \times E$ interaction model. So, in the future breeding experiments for the development of these two traits proper design and analysis needs to be done for consideration of $\mathrm{G} \times \mathrm{E}$ interaction. However, in other characters due to significant $X^{2}$ values the situation becoming more complex as $\mathrm{G} \times \mathrm{E}$ interaction model is inadequate to explain the genetic nature of these traits and hence for their genetic explanation need more generations as well as need to extend the $G \times E$ interaction model including other parameters like non-allelic interaction and linkage either individually or both at a time.

\section{Conclusions}

It is now recognized that $\mathrm{G} \times \mathrm{E}$ interaction is an important source of phenotypic variations. As under the control of gene, breeders are trying to produce and select suitable cultivars, which gave maximum economic yield over a range of environments with wider adaptabilities and stabilities. In the breeding program usually many potential genotypes are 
evaluated in different environments before selecting certain desirable traits. In the present investigation, chi-square values for all the characters except bulb length and neck length are found to be significant which reveal that except additive genetic, dominance genetic and $G \times E$ interaction effects the other genetical effects may present in these traits that's why need to enlarge the $G \times E$ interaction model including linkage and non-allelic parameters either individually or both for getting the exact genetic information of these bulb yield contributing traits as well as stable onion genotypes over all the agro climatic regions.

\section{Acknowledgements}

Authors sincerely express their deep respect to Late Professor Dr. Md. Abdul Khaleque, Department of Botany, University of Rajshahi, Rajshah-6205, Bangladesh for the technical assistance during the experiment and analysis.

\section{References}

Anonymous (1988). Production of Year Book. Food and Agricultural Organization of the United Nations, Rome, Italy. 42.

Azad, A.K. (1991). Studies on variability and genotypeenvironment interaction based on space seedling as environment in Lentil (Lens culinaris Medic.). M.Sc. Thesis, Rajshahi University, Bangladesh.

BBS (2019). Yearbook of Agricultural Statistics of Bangladesh-2019. http://www.bbs.gov.bd/. Accessed: 1 January 2021.

Breese, E.L. (1969). The measurement and significance of genotype - environmental interactions in grasses. Heredity, 24:27-44.

Brewster, J.L. (2008). Onions and other vegetable Alliums (2nd Edition). CAB International, Wallingford, Oxfordshire, OX10 8DE, UK. p. 1-413.

Bucio Alanis, L. (1966a). Environmental and genotypeenvironmental components of variability: I. Inbred lines. Heredity, 21:387-397.

Bucio Alanis, L., \& Hill, J. (1966b). Environmental and genotype- environmental components of variability. II. Heterozygotes. Heredity, 21:399-405.

Bucio Alanis, L., Perkins, J.M., \& Jinks, J.L. (1969). Environmental and genotype-environmental components of variability. V. Segregating generations. Heredity, 24:115-127.

Comstock, R.E., \& Moll, R.H. (1963). Genotype environment interaction. In: Statistical Genetics and Plant Breeding. W.D. Hanson and H.F. Robinson (ed.), National Academy of Sciences and of the National Research Council, 982:164-196.

Eberhart, S.A., \& Russell, W.A. (1966). Stability parameters for comparing varieties. Crop Science, 6:36-40.
FAO (2019). Food and Agriculture Organization, Statistics Division (FAOSTAT). 2020. Retrieved 19 February 2021.

Finlay, K.W., \& Wilkinson, G.N. (1963). The analysis of adaptation on a plant breeding programme. Australian Journal of Agricultural Research, 14:742-754.

Golani, I.J., Vaddoria, M.A., Mehta, D.R., Naliyadhara, M.V., \& Dobariya, K.L. (2005). Genotype × environment interaction and stability analysis in red onion (Allium cepa L.). Indian Journal of Agricultural Research, 39:307-309.

Immer, F.R., Hayes, H.K., \& Powers, L. (1934). Statistical determination of barley varietal adaptation. Agronomy Journal, 26:403-419.

Jahromi, A.A., \& Amirizadeh, S.R. (2015). Production potential of onion (Allium cepa L.) as influenced by different transplant ages. Indian Journal of Fundamental and Applied Life Sciences, 5:118-121.

Jinks, J.L., \& Mather, K. (1955). Stability in development of heterozygotes and homozygotes. Proceedings of the Royal Society B: Biological Sciences, 143:561578.

Jokanovic, M.B., Girek, Z., Ugrinovic, M., Sikora, V., Dalovic, I., \& Zdravkovic, J. (2016). AMMI model in the analysis of genotype by environment interaction of conventionally and organically grown onion. Genetika, 48:1027-1038.

Jones, H.A., \& Mann, L.K. (1963). Onions and Their Allies. Leonard Hill (Books) Ltd. London.

Mather, K. (1949). Biometrical Genetics (1 $1^{\text {st }}$ Edition). Methuen and Co. Ltd., London.

Mather, K., \& Jones, R.M. (1958). Interaction of genotype and environment in continuous variation. I Description. Biometrics, 14:343-359.

Mila, F.A., \& Parvin, M.T. (2019). Forecasting area, production and yield of onion in Bangladesh by using ARIMA model. Asian Journal of Agricultural Extension, Economics \& Sociology, 37:1-12.

Perkins, J.M., \& Jinks, J.L. (1968). Environmental and genotype - environmental components of variability. III. Multiple lines and crosses. Heredity, 23:339-356.

Sekara, A., Pokluda, R., Del Vacchio, L., Somma, S., \& Caruso, G. (2017): Interactions among genotype, environment and agronomic practices on production and quality of storage onion (Allium cepa L.) - A review. Horticultural Science - Prague, 44:21-42.

Singh, S., \& Pawar, I.S. (2005). Theory and application of biometrical genetics ( $1^{\text {st }}$ Edition). CBS Publishers \& Distributors Pvt. Ltd., New Delhi-110002, India.

Tahir, M., Aleem, S., Munawar, M., Parveen, N., Amin, E., Aslam, R., Saeed, A., \& Najeebullah, M. (2020). GGE biplot an effective tool to study genotype and genotype $\times$ environment interaction; a case study in onion (Allium cepa L.). Pakistan Journal of Agricultural Sciences, 57:1565-1571.

Yates, F., \& Cochran, W.G. (1938). The analysis of groups of experiment. Journal of Agricultural Science, 28:556-580. 